\title{
Planning of River System Connection Project in Panggong District of Xiangyang
}

\author{
Sun Lingkai ${ }^{1, a}$, Zhang Wenlu ${ }^{2}$ and Zheng Hezhen ${ }^{1}$ \\ ${ }^{1}$ Changjiang Survey, Planning, Design and Research Co., Ltd. Wuhan, China \\ ${ }^{2}$ Wuhan East Lake High-tech Development Zone. Wuhan, China
}

\begin{abstract}
Panggong District, surrounded by the Han River on three sides, is close to Xiangyang Ancient City. It is the key area of strategic layout of Xiangyang's urbanization development. The low-lying topography and high-level underground water with a lack of drainage channel and rainwater storage area cause a serious problem of drainage and waterlogging prevention in this region. A river system connection project was planned to solve this problem, in which new river systems were excavated and necessary gates and pumping stations were constructed to improve the capacity of drainage and waterlogging prevention of the region. Furthermore, the operation schemes of the connection project were determined in flood season and dry season, the project benefit was analysed, and related problems were discussed.
\end{abstract}

\section{Introduction}

Xiangyang is located in the middle reach of the Han River. As a sub-central city of Hubei Province, it is a national historical and cultural city with well-developed river system. Panggong District is adjacent to Xiangyang Ancient City, set beside Xian Mountains and surrounded by the Han River on three sides. It is the key area of strategic layout of Xiangyang's urbanization development with the advantage of natural conditions and an enormous potential for development.

Due to the low-lying topography, the rising of groundwater level after impoundment of Cuijiaying hydro-junction of the Han River (located in the south of the area) and the lack of drainage channels and rainwater storage areas of Panggong District, water could be easily accumulated due to heavy rainstorms, resulting in the serious problems of drainage and waterlogging prevention. Therefore, it is urgent to solve the problems.

Changjiang Survey, Planning, Design and Research Co., Ltd. has done a lot of work about the river system connection project in Panggong District. The purpose of writing this paper was to present the planning of this project, which could help readers understand this project clearly.

\section{Planning principle}

According to the arrangement of detailed regulatory plan and drainage plan of Panggong District, the standard of drainage and waterlogging prevention in Panggong District was raised to the frequency of once-in-30 years through the construction of new storage lakes, drainage channels, regulating sluices, drainage gates and drainage pumping stations. The Han River, Xiangshui River and the moat were connected by excavating new river systems, enough water can be diverted to Panggong District in the dry season, and the hydrodynamic conditions in rivers were enhanced. Waterfront landscape can be built relying on the connection of river system, and a composite urban green corridor is created with the integration of ecological livability, cultural exhibition, tourism and modern commerce, et al ${ }^{[1]}$.

\section{Overall layout and scale determination of the project}

\subsection{Overall layout of the Project}

The river system connection project in Panggong District (Figure 1) is laid out according to the project system of "Two horizontal rivers run through a vertical river, three rivers and one lake". The layout of the three rivers is as follows: Jianghua River is excavated in the central part of the region from east to west, beginning from Xiangyang moat and ending in the Han River; Xiangyang River is excavated in the south of Jianghua River along Xiangyang Road from east to west, and the west outlet of which connects to Xiangshui River; Panggong River is excavated from north to south, and the south outlet of which connects to the Han River. The Panggong Central Park Lake is excavated at the intersection of Jianghua River and Panggong River. The layout of gates and pumping stations is as follows: four check gates are arranged in regional sharding positions, locating in the moat, Xiangshui River, the upper reach of Jianghua River and the middle reach of Panggong River, respectively; Jianghua drainage gate is arranged at the junction of Jianghua River and Han River; Tangcheng

\footnotetext{
${ }^{a}$ Corresponding author: sunlingkai@cjwsjy.com.cn
} 
drainage gate and Tangcheng drainage pumping station are arranged at the intersection of Panggong River and Han River.

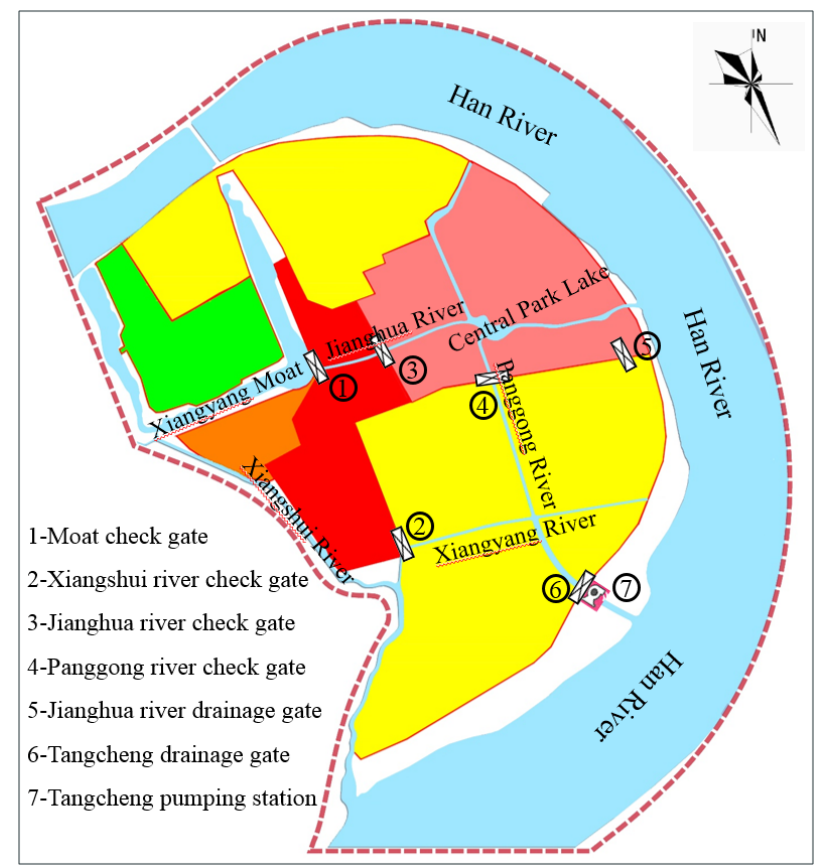

Figure 1. The Overall Layout of the Project.

\subsection{Scale Determination of the Project}

According to the Chinese newly revised $<<$ Outdoor Drainage Design Code $>>($ GB50014-2006) in 2016, the drainage standard of the river system connection project is determined to be the frequency of once-in-30 years, and the normal water level in dry season is consistent with the normal storage level of Cuijiaying hydrojunction, which is $62.73 \mathrm{~m}$. In order to avoid the water of Han River entering the city to cause flood, when the water level of Han River reaches the value of frequency of once-in-20 years, the drainage gate should be closed and the pumping station should be used to drain the flood, and the initial drainage level of the pumping station is $63.15 \mathrm{~m}$. Furthermore, the design water level of the river and lake is $64.5 \mathrm{~m}$, which is $1 \mathrm{~m}$ below the lowest road surface.

On this basis, through the runoff generation, confluence calculation and flood regulation calculation, the design discharge and main scale control indexes of river-lake system were put forward, in which the lake surface area is 11.8 hectares, and related indexes for the scale of the river are shown in table 1 .

Table 1. The table of river design parameters.

\begin{tabular}{|c|c|c|c|c|c|}
\hline $\begin{array}{c}\text { River } \\
\text { name }\end{array}$ & $\begin{array}{c}\text { Channel } \\
\text { length } \\
(\mathbf{m})\end{array}$ & $\begin{array}{c}\text { Design } \\
\text { flow } \\
\left(\mathbf{m}^{\mathbf{3}} / \mathbf{s}\right)\end{array}$ & $\begin{array}{c}\text { Normal } \\
\text { water } \\
\text { level } \\
\text { width } \\
(\mathbf{m})\end{array}$ & $\begin{array}{c}\text { Design } \\
\text { water } \\
\text { level } \\
\text { width } \\
(\mathbf{m})\end{array}$ & $\begin{array}{c}\text { Surface } \\
\text { area } \\
(\mathbf{h a})\end{array}$ \\
\hline $\begin{array}{c}\text { Upper } \\
\text { Jianghua } \\
\text { river }\end{array}$ & 1507 & 15 & $15-20$ & 50 & 2.64 \\
\hline $\begin{array}{c}\text { Lower } \\
\text { Jianghua }\end{array}$ & 835 & 30 & $15-46$ & $50-80$ & 2.55 \\
\hline
\end{tabular}

\begin{tabular}{|c|c|c|c|c|c|}
\hline river & & & & & \\
\hline $\begin{array}{c}\text { Upper } \\
\text { Panggong } \\
\text { river }\end{array}$ & 1214 & 20 & $15-20$ & 50 & 2.82 \\
\hline $\begin{array}{c}\text { Middle } \\
\text { Panggong } \\
\text { river }\end{array}$ & 1006 & 50 & $20-25$ & 55 & 2.26 \\
\hline $\begin{array}{c}\text { Lower } \\
\text { Panggong } \\
\text { river }\end{array}$ & 835 & 105 & $30-35$ & 65 & 2.71 \\
\hline $\begin{array}{c}\text { Xiangyang } \\
\text { river }\end{array}$ & 2545 & 30 & $15-20$ & 50 & 4.45 \\
\hline
\end{tabular}

Considering the relationship between inflow and outflow among rivers, lakes, gates, and pumping stations, the following equations were established to determine the scale of gates and pumping stations based on the principle of water balance.

$$
\begin{gathered}
Q_{p}=f\left(H_{0}, H_{\mathrm{i}}\right) \\
Q_{\mathrm{g}}=f\left(H_{0}, H_{\mathrm{i}}\right) \\
Q_{\mathrm{l}}-Q_{\mathrm{b}}=\left(V_{1}-V_{0}\right) / \Delta t
\end{gathered}
$$

Where $Q_{\mathrm{p}}$ is the discharge of pumping station; $Q_{\mathrm{g}}$ is the discharge of gate; $Q_{\mathrm{i}}$ is the discharge of drainage area; $Q_{0}$ is the total discharge; $H_{\mathrm{o}}$ is the water level of Han River; $H_{\mathrm{i}}$ is water level of the Central Park Lake; $V_{0}$ is the water volume at the beginning of time; $V_{1}$ is the water volume at the end of time; $\Delta t$ is the time interval.

The design scales of gates and pumping stations were determined according to the following formulas: the design discharge of the four check gates in the moat, Xiangshui river, the upper reach of Jianghua river and the middle reach of Panggong river is 10, 30, 10 and 30 $\mathrm{m}^{3} / \mathrm{s}$, respectively; the design discharge of the Jianghua river drainage gate is $30 \mathrm{~m}^{3} / \mathrm{s}$, and design discharge of the Tangcheng drainage gate is $105 \mathrm{~m}^{3} / \mathrm{s}$; the design discharge of the Tangcheng pumping station is $35 \mathrm{~m}^{3} / \mathrm{s}$.

\section{Design Scheme of rivers and lakes}

The design of river-lake system connection project should be based on the local conditions with the comprehensive considerations of many factors, such as requirements of river-lake flow, storage volume and coordination of surrounding environment. It is important that the design of revetment should reflect the ecology and hydrophilicity of urban water system. The following design scheme of the project was proposed based on the current experience of ecological river and lake design at home and abroad and combined with the actual situation of Panggong District ${ }^{[2]}$.

Considering that the Central Park should reserve enough green space for future main entertainment venues for residents, the ecological gentle slope type revetment is adopted for the design of the lake, including two-grade gentle slopes, as shown in Figure 2. The first grade slope is located below the normal water level, on which the cultivation platform of aquatic plants is decorated. The second grade slope is located above the normal water level, on which the cultivation platform of landscape green plants is decorated. The footpath is 
attached to the top of the second slope with landscape green belt outside of it. The design scheme can not only meet the requirements of water ecology and water environment, but also save the construction cost with landscape planting, sod revetment and aquatic plants planting at low cost ${ }^{[3]}$.

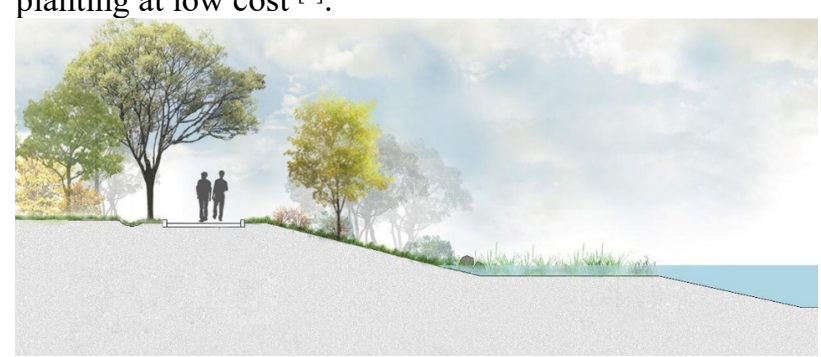

Figure 2. The design scheme of lake revetment.

Due to the limitation of the width of green space and the requirement of flow capacity, the combined slopewall revetment was selected after comprehensive comparison for the design of the river, which has been used in river system connection projects in Shanghai, Hangzhou, Chengdu and other cities. Ecological lattice bin stone cages are arranged below the normal water level of the river with the attaching of landscape planting slope protection on the top, and the slope is above the normal water level. The footpath is attached to the top of the slope, with landscape green belt outside it. This design scheme not only has the advantages of fulfilling the flow capacity of the river, reducing the amount of earthwork excavation and saving the project investment, but also has better landscape. The ecological lattice bin stone cages are underwater all year round, and turf and shrubs can be planted on the uphill surface. The whole revetment forms a continuous ecological landscape corridor of the river ${ }^{[4]}$, as shown in Figure 3.

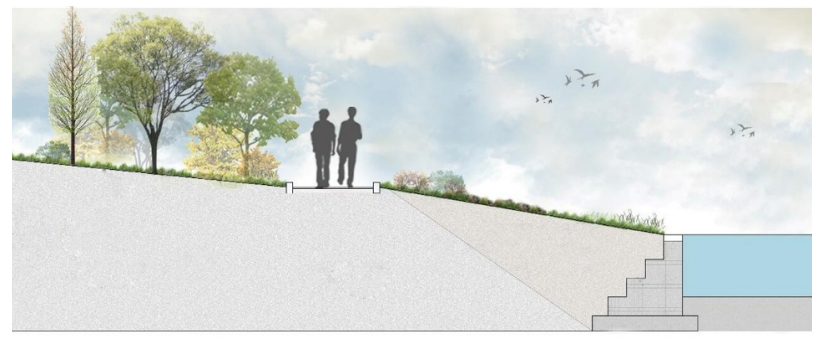

Figure 3. The design scheme of river revetment.

\section{Operation scheme}

The operation scheme in flood season is as follows: when the water level of Han River is lower than $63.15 \mathrm{~m}$, the four check gates in the Xiangshui River, the moat, the upper reach of the Jianghua River and the middle reach of Panggong River should be closed, respectively. Meanwhile, the Jianghua River drainage gate and the Tangcheng drainage gate should be opened, while Tangcheng pumping station should be closed. The water in the upper area can be spontaneously drained into the Han River through the Jianghua river drainage gate, and the water in the lower area can be drained through the Tangcheng drainage gate to the Han River. When the water level of Han River is higher than $63.15 \mathrm{~m}$, the three check gates in the Xiangshui River, the moat and the upper reach of the Jianghua River should all be closed, and the Jianghua River drainage gate and the Tangcheng drainage gate should also be closed, but the check gate in the middle reach of the Panggong River should be opened. The water of upper and lower areas will converge to the Tangcheng pumping station and can be pumped to Han River.

The operation scheme in dry season is as follows: in order to ensure the ecological discharge of the Panggong District in the dry season, the four check gates in the moat, Xiang River, the upper reach of Jianghua River and the middle reach of Panggong River should be all opened, and the Jianghua River and the Tangcheng drainage gates should also be opened. Therefore, water can be diverted from the moat and Xiangshui River to the Panggong River system, flowing through the Jianghua River, the Panggong River and the Xiangyang River, finally into Han River, which can smooth the river system in the area and enhance the hydrodynamic condition.

\section{Benefit analysis}

Implementing the river system connection project in Panggong District can increase regional water storage and flood drainage ability, achieving spontaneous or pump drainage of flood water and supporting the rivers and lakes which play infrastructural roles in the drainage and waterlogging prevention system. Furthermore, the moat, Xiangshui River and Han River can be connected through excavating new river system, which can build beautiful landscape, improve the living environment of urban residents and enhance the quality of the city. This project will lay a solid foundation for building ecological and livable environment in Panggong District ${ }^{[5]}$.

\section{Conclusions}

Panggong District is surrounded by the Han River on three sides without any natural river in the area. This planning could solve the problems of drainage and waterlogging prevention by establishing new river systems and arranging drainage structures. The following tasks should be done for the planning of river system connection project along the river according to the research ${ }^{[6]}$.

(1) The water level of Han River, the regional rainstorm duration and the process of runoff generation and confluence should be accurately analyzed. The standards of drainage standards, scales of rivers, lakes and drainage structures should be reasonably determined. Reasonable operation mode in flood season should be formulated to ensure clear drainage process.

(2) On the basis of solving the problems of regional drainage and waterlogging prevention, it is necessary to formulate a reasonable water supply scheme in dry season to ensure water exchange and smooth regional river-lake system.

(3) Ecology and hydrophilicity of river systems should be included in the design process of the river-lake connection project, and the ecological flexible revetment 
should be adopted as much as possible. Reasonable upper structure type should be selected to make sure that the drainage structures are coordinated with surrounding environment.

\section{Acknowledgements}

This paper was supported by Changjiang Survey, Planning, Design and Research Co., Ltd. (CX2017Z37).

Conflicts of Interest: The authors declare no conflict of interest.

\section{References}

1. Zhao Junkai, Jiang Chenjuan, Zhu Mingxia, et al. Study on river-lake relationship and interconnected river system network [J].South-to-North Water Transfers and Water Science Technology. 2015(6). (In Chinese)

2. Li Yuanyuan, Huang Huojian, Li Zongli, et al. Practical Experience and Development Trend of the Interconnected River System Network [J]. Southto-North Water Transfers and Water Science Technology. 2014(4). (In Chinese)

3. Xun Gang. Ecological design of Tongzhou district river revetment in Nantong [J]. China Water Transport. 2017(5). (In Chinese)

4. Tang Aixue. Application of lattice bin stone cages in ecological slope protection construction of water conservancy project $[\mathrm{J}]$. Architectural Engineering Technology and Besign. 2015(14). (In Chinese)

5. Liu Bojuan, Zheng Qiuliang, Zou Chaowang. Study on necessity of project construction for connecting rivers and lakes [J]. Yangtze River. 2014(16). (In Chinese)

6. Wang Guoti, Li Dezhang, Li Jianzhang. Research on diversity and adaptability of ecological resortment of river embankment in cities [J]. Journal of Hefei University of Technollogy(Natural Scienge). 2009(8). (In Chinese) 